\title{
SURVEY PERILAKU HIDUP BERSIH DAN SEHAT ANAK USIA DINI DI ERA PANDEMI COVID-19 DI DESA PURWODADI KECAMATAN GISTING KABUPATEN TANGGAMUS
}

\author{
${ }^{1}$ Sri Suharti, ${ }^{2}$ Sarinah Sri Wulan, 3Edita izni fauziah, Akademi Keperawatan Baitul Hikmah Bandar Lampung \\ Email:srisuharti1977@gmail.com
}

\begin{abstract}
Abstrak
Prevalensi Covid-19 di Indonesia 927.380 kasus,pandemi Covid-19 bisa di cegah dengan PHBS.Perilaku hidup bersih dan sehat (PHBS) adalah suatu kegiatan atau aktivitas mahluk hidup yang dapat di amati secara langsung maupun tidak langsung yang dapat diamati oleh pihak luar. Penelitian ini bertujuan untuk mengetahui gambaran perilaku hidup bersih dan sehat anak usia dini di era pandemi Covid-19 di Desa Purwodadi Kecamtan Gisting Kabupaten Tanggamus. Penelitian ini menggunakan penelitian jenis deskriptif. Responden berjumlah 30 orang tua yang memiliki anak usia dini 4-6 tahun yang di ambil menggunakan tekhnik total sampling. Instrumen yang di gunakan untuk mengetahui gambaran perilaku hidup bersih dan sehat menggunakan kuesioner PHBS dari Anhusadar.Hasil dari penelitian menunjukkan $90 \%$ atau 27 responden menunjukan baik perilaku hidup bersih dan sehat sedangkan $10 \%$ atau 3 responden menunjukan perilaku hidup bersih dan sehat cukup. Gambaran perilaku hidup bersih dan sehat anak usia dini di era pandemi Covid-9 di Desa Purwodadi Kecamatan Gisting Kabupaten Tanggamus tahun 2021 dalam kategori baik. Penelitian ini bisa di lanjutkan dengan responden yang lebih banyak dan bisa di lakukan dengan responden anak usia dini secara langsung
\end{abstract}

Kata Kunci : anak usia dini, Perilaku hidup bersih dan sehat

\begin{abstract}
The prevalence of Covid-19 in Indonesia is 927,380 cases, the Covid-19 pandemic can be prevented with PHBS. Clean and healthy living behavior (PHBS) is an activity or activity of living things that can be observed directly or indirectly that can be observed by outsiders. This study aims to describe the clean and healthy behavior of early childhood in the era of the Covid-19 pandemic in Purwodadi Village, Gisting District, Tanggamus Regency. This study uses a descriptive type of research. Respondents amounted to 30 parents who have children aged 4-6 years who were taken using a total sampling technique. The instrument used to determine the description of clean and healthy living behavior was using the PHBS questionnaire from Anhusadar. The results of the study showed $90 \%$ or 27 respondents showed good clean and healthy living behavior while $10 \%$ or 3 respondents showed sufficient clean and healthy living behavior. The description of clean and healthy behavior for early childhood in the era of the Covid-9 pandemic in Purwodadi Village, Gisting District, Tanggamus Regency in 2021 in the good category. This research can be continued with more respondents and can be done with early childhood respondents directly
\end{abstract}

Keywords: clean and healthy living behavior, early childhood 


\section{PENDAHULUAN}

Coronanvirus adalah salah satu virus berbahaya yang dapat menyebabkan penyakit dengan berbagai gejala mulai dari gejala yang ringan hingga berat. Setidaknya ada dua jenis corona virus yang diketahui menyebabkan penyakit yang dapat menimbulkan gejala berat seperti Middle East Respiratory Syndrome (MERS) dan Severe Acute Respiratory Syndrome (SARS). Corona virus Disease 2019 (Covid-19) adalah penyakit jenis baru yang belum pernah diidentifikasi sebelumnya pada manusia. Virus penyebab Covid-19 ini dinamakan SarsCoV-2. Virus corona adalah zoonosis (ditularkan antara hewan dan manusia). Penelitian menyebutkan bahwa SARS ditransmisikan dari kucing luwak (civet cats) ke manusia dan MERS dari unta ke manusia. Adapun, hewan yang menjadi sumber penularan Covid-19 ini masih belum diketahui (Kemenkes, 2020)

Tanda dan gejala umum infeksi Covid-19 antara lain gejala gangguan pernapasan akut seperti demam, batuk dan sesak napas. Masa inkubasi rata-rata 5-6 hari dengan masa inkubasi terpanjang 14 hari, Pada kasus Covid-19 yang berat dapat menyebabkan pneumonia, sindrom pernapasan akut, gagal ginjal, dan bahkan kematian. Tanda tanda dan gejala klinis yang dilaporkan pada sebagian besar kasus adalah demam, seperti beberapa kasus mengalami kesulitan bernapas, dan hasil rontgen menunjukkan infiltrat pneumonia luas di kedua paru (Kemenkes, 2020).
Menurut World Health Organization (WHO ) 2019 melalui country office china melaporkan kasus pneumonia yang tidak diketahui etiologinya di Kota Wuhan, Provinsi Hubei, Cina. Pada tanggal 7 Januari 2020, Cina mengidentifikasi pneumonia yang tidak diketahui etiologinya tersebut sebagai jenis baru Coronavirus (coronavirus disease, Covid-19). Tanggal 30 Januari 2020 WHO telah menetapkan sebagai Kedaruratan Kesehatan Masyarakat Yang Meresahkan Dunia/ Public Health Emergency of International Concern (KKMMD/PHEIC). Penambahan jumlah kasus Covid-19 berlangsung cukup cepat hingga kasus yang terinfeksi Covid-19 di bulan januari sudah mencapai 95 juta kasus. Menurut World Health Organization (WHO) : Dunia di ambang Bencana moral karena kasus infeksi Covid-19 di dunia menunjukkan tren angka penularan masih terus meningkat, terlebih di bulan januari kasus positif Covid-19 meningkat lebih tajam dengan mencapai total kasus 95.966.527 juta orang (Bramasta, 2021 ), diantara kasus tersebut, sudah ada beberapa petugas kesehatan yang dilaporkan terinfeksi. Tanggal 2 maret 2020 Indonesia melaporkan kasus Covid-19 sebanyak 2 orang yang terjangkit Covid-19, sejak hari itu jumlah kasus positif Covid-19 semakin bertambah dari hari kehari bahkan di bulan januari 2021 kasus positif-19 sudah mencapai angka 927.380 kasus (Moerti, 2021). 
Lampung juga waspada kasus positif Covid19, setiap harinya bertambah dari mulai 1 pasien positif Covid-19, hingga saat ini sudah mencapai 9.318 kasus di bulan januari 2021( Hadiyatna, 2021).

Satgas penanganan Covid-19 kabupaten tanggamus memperketat protokol kesehatan kepada seluruh masyarakat, karena di tetapkan kabupaten sebagian zona merah. Satgas melakukan gerakan cepat untuk menyikapi kabupaten tanggamus yang sudah di tetapkan sebagai zona merah. Pasien positif Covid-19 di tanggamus di bulan januari 2021 sudah mencapai 492 kasus (Pemda dalam Hidayat, 2021).

Virus Covid-19 sangat cepat sekali penularanya bahkan sudah sampai di kecamatan gisting kabupaten tanggamus di temukannya pasien Covid- 19 di gisting pertama kali di desa purwodadi dengan jumlah yang terkena 1 orang, sehingga gugus tugas pencegahan Covid-19 kabupaten tanggamus menutup akses pasar gisting selama tiga hari, yaitu pada tanggal 20-24 Oktober 2020. Penutupan dilakukan setelah hasil swab terhadap pedagang dan warga di sekitar pasar gisting di temukan 5 orang positif Covid-19 atau virus corona bahkan saat ini yang terinfeksi Covid-19 di kecamatan gisting kabupaten tanggamus di bulan januari 2021 sudah mencapai 65 kasus (Pemda dalam Hidayat, 2021).
Dampak dari pandemi covid-19 sangat mempengaruhi budaya, politik, pendidikan dan juga telah menimbulkan tekanan sosial . Ekonomi masyarakat hampir di seluruh Negara mengalami masalah yang dilematis antara menyelamatkan negaranya atau keselamatan hidup warganya. Yang tentu perekonomian negara tersebut pastinya akan menyelamatkan warga negaranya ( Ramlan, $2020)$.

Solusi dalam pencegahan Covid-19 dengan cara menerapkan perilaku hidup bersih sehat (PHBS) yaitu membiasakan diri hidup bersih sehat dilingkungan sejak dini. Kegiatan paling sederhana yang dapat dilakukan oleh orang tua adalah mengajarkan anak untuk supaya terbiasa hidup bersih dengan cara, meletakkan alas kaki pada tempatnya; menggunakan alas kaki jika hendak keluar rumah; membuang sampah pada tempatnya; meletakkan peralatan makan minum yang kotor pada tempatnya; membersihkan mainan; menutup mulut pada saat batuk dan bersin; menjauhi asap rokok, asap pembakaran sampah, asap kendaraan bermotor; serta buang air besar (BAB) dan buang air kecil (BAK) di toilet.

\section{METODOLOGI}

Desain penelitian ini menggunakan metode penelitian deskriptif. Penelitian deskriptif merupakan penelitian yang bertujuan untuk mendeskripsikan atau memaparkan peristiwaperistiwa penting yang terjadi pada masa kini. Deskripsi peristiwa dilakukan secara sistematis dan lebih menekankan pada data factual dari pada 
penyimpulan (Nursalam, 2016 di kutip dalam pertama, 2018).

Populasi adalah wilayah generalisasi yang terdiri atas: obyek/subyek yang mempunyai kualitas dan karakteristik tertentu yang ditetapkan oleh peneliti untuk dipelajari dan kemudian ditarik kesimpulannya (Sugiono, 2016 di kutip dalam Nanda, 2017). Populasi dalam penelitian ini adalah orang tua yang memiliki anak berumur 4-6 tahun yang berada di Desa Purwodadi Kecamatan Gisting Kabupaten Tanggamus dengan jumlah 30 kk.

Instrumen penelitian yang digunakan dalam adalah kuesioner. Kuesioner merupakan daftar pertanyaan yang digunakan peneliti untuk memperoleh informasi dari responden(Nursalam, 2016)

Langakah-langkah pengumpulan data penelitian adalah Persiapan mengurus perizinan antara institusi kepala desa purwodadi, menjelas kan maksud, tujuan, dan waktu penelitian pada kepala desa purwodadi atau petugas yang bertanggung jawab di tempat penelitian dan meminta persetujuan, meminta data penduduk desa purwodadi di kepala desa. Pelaksanaan : Menjelaskan maksud dan tujuan penelitian pada Orang tu, menjelaskan kepada orang tua tentang prosedur penelitian yang akan dilakukan, meminta tanda tangan inform consent orang tua, melakukan wawancara dengan orang tua responden, mengisi kuesioner dengan orang tua responden , melaksanakan pengolahan data, menyajikan pengolahan dalam bentuk deskriptif.

\section{HASIL}

Pengambilan data penelitian ini dilakukan di Desa Purwodadi Kecamtan Gisting Kabupaten Tanggamus dengan karakteristik responden 30 orang responden terdapat 11 (37\%) responden berjenis kelamin laki-laki dan $19(63 \%)$ responden berjenis kelamin perempuan dan sebagai besar perilaku hidup bersih dan sehat anak usia dini dalam katagori baik sebanyak 27 (90\%).

Karakteristik responden dapat dilihat pada table 1.

Tabel 1.Karakteristik responden berdasarkan jenis kelamin

\begin{tabular}{cccc}
\hline NO & Jumlah kelamin & $\begin{array}{c}\text { Frekuensi } \\
(\boldsymbol{F})\end{array}$ & $(\%)$ \\
\hline 1 & Laki-laki & 11 & 37 \\
2 & Perempuan & 19 & 63 \\
\hline & Jumlah & $\mathbf{3 0}$ & $\mathbf{1 0 0}$ \\
\hline
\end{tabular}

Tabel 2. Karakteristik responden berdasarkan usia

\begin{tabular}{cccc}
\hline NO & Jenis usia & $\begin{array}{c}\text { Frekuensi } \\
(\boldsymbol{f})\end{array}$ & $(\boldsymbol{\%})$ \\
\hline 1 & 4 tahun & 6 & 20 \\
2 & 5 tahun & 13 & 43 \\
3 & 6 tahun & 11 & 37 \\
\hline & Jumlah & $\mathbf{3 0}$ & $\mathbf{1 0 0}$ \\
\hline
\end{tabular}

Berdasarkan tabel 2 diatas dapat dilihat bahwa dari 30 orang responden terdapat 6 (20\%) usia 4 tahun, responden yang usia 5 tahun 13 (43\%) dan responden usia 6 tahun 11 (37\%).

Tabel 3. Karakteristik responden berdasarkan agama

\begin{tabular}{cccc}
\hline NO & Agama & $\begin{array}{c}\text { Frekuensi } \\
(\boldsymbol{F})\end{array}$ & (\%) \\
\hline 1 & Islam & 30 & 100 \\
2 & Kristen & 0 & 0 \\
& protestan & & \\
\hline
\end{tabular}




\begin{tabular}{cccc}
\hline 3 & Kristen & 0 & 0 \\
& katolik & & \\
4 & Hindu & 0 & 0 \\
5 & Buddha & 0 & 0 \\
6 & Konghucu & 0 & 0 \\
\hline & Jumlah & $\mathbf{3 0}$ & $\mathbf{1 0 0}$ \\
\hline
\end{tabular}

Berdasarkan tabel 3 di atas dapat dilihat bahwa dari 30 responden beragama islam (100\%), kristen protestan $(0 \%)$, kristen katolik $(0 \%)$, hindu (0\%), Buddha (0\%), konghucu (0\%).

Fgfgh Karakteristik pendidikan orang tua responde

Tabel 4.Karakteristik pendidikan orang tua responden

\begin{tabular}{cccc}
\hline NO & Pendidikan & Frekuensi & (\%) \\
\hline 1 & Sekolah dasar & 0 & 0 \\
2 & SMP & 11 & 37 \\
3 & SMA & 13 & 43 \\
4 & Perguruan tinggi & 6 & 20 \\
\hline & Jumlah & $\mathbf{3 0}$ & $\mathbf{1 0 0}$
\end{tabular}

Berdasarkan tabel 4 diatas dapat dilihat bahwa dari 30 orang tua responden $0(0 \%)$ sekolah dasar, 11 (37\%) orang tua responden berpendidikan SMP, $13(43 \%)$ orang tua responden berpendidikan SMA, 6 (20\%) orang tua responden berpendidikan perguruan tinggi.

Tabel 3 Hasil perilaku hidup bersih dan sehat (PHBS) responden

\begin{tabular}{cccc}
\hline NO & $\begin{array}{c}\text { hasil phbs anak } \\
\text { usia dini }\end{array}$ & $\begin{array}{c}\text { Frekuensi } \\
(\boldsymbol{f})\end{array}$ & $(\boldsymbol{\%})$ \\
\hline $\mathbf{1}$ & Baik & 27 & 90 \\
$\mathbf{2}$ & Cukup & 3 & 10 \\
$\mathbf{3}$ & Kurang & 0 & 0 \\
\hline & Jumlah & $\mathbf{3 0}$ & $\mathbf{1 0 0}$ \\
\hline
\end{tabular}

Bedasarkan table 4.2 di atas dilihat bahwa dari 30 responden terdapat $3(10 \%)$ dengan perilaku hidup bersih dan sehat cukup, 27
(90\%) perilaku hidup bersih dan sehat baik di

Desa Purwodadi Kecamatan Gisting Kabupaten Tanggamus tahun 2021

\section{PEMBAHASAN}

1. Karakteristik responden

a. Karakteristik responden berjenis kelamin

Berdasarkan hasil penelitian dapat di lihat bahwa dari 30 orang responden terdapat $11(37 \%)$ responden berjenis kelamin laki- laki dan 19 ( 63\%) responden berjenis kelamin perempuan di Desa Purwodadi Kecamatan Gisting Kabupaten Tanggamus tahun 2021.

Hasil penelitian Rohman mengatakan bahwa tidak ada hubungan bermakna antara jenis kelamin dengan PHBS pada tatanan rumah tangga di wilayah Desa Menco Kecamatan Wedung Demak.

b. Karakteristik responden berdasarkan usia

Berdasarkan tabel 4.2 diatas dapat dilihat bahwa dari 30 orang responden terdapat $6(20 \%)$ usia 4 tahun, responden yang usia 5 tahun 13(43\%) dan responden usia 6 tahun 11(37\%) di Desa Purwodadi Kecamatan Gisting Kabupaten Tanggamus tahun 2021 Dilihat dari hasil penelitian perilaku hidup bersih dan sehat (PHBS) yang baik berusia 5-6 tahun di karnakan semakin bertambah usia akan semakin 
berkembang pula daya tangkap dan pola pikirnya, sehingga pengetahuan yang diperolehnya semakin membaik, karna adanya pertambahan usia yang di iringi bertambahnya fisik (anatomi) dan struktur tubuh dalam arti sebagian atau seluruhnya ada multiplikasi (bertambah banyaknya) sel-sel tubuh dan juga bertambahnya sel. Perkembangan adalah bertambahnya kemampun dan struktur fungsi tubuh yang lebih komplek dalam pola yang di atur, dapat diperkirakan dan diramalkan sebagai hasil dari proses diferensi sel, jaringan tubuh, organorgan dan sistemnya yang terorganisasi (Nursalam, 2008 di kutip dalam C.Pinem 2019).

Hal ini sesuai dengan penelitian C.Pinem 2019 tentang gambaran perilaku hidup dan sehat (PHBS) siswa/siswi SD negri 043951 kelas IV,V, VI Desa Surbakti Kecamatan Simpang Empat kabupaten Karo tahun 2019 yang hasilnya adalah pengetahuannya baik sebanyak $71,6 \%$, sikap nya baik sebanyak $84,5 \%$ kemudian tindakannya baik sebanyak 71,4\% tentang PHBS.

c. Karakteristik responden berdasarkan agama

Berdasarkan tabel 4.3 di atas dapat dilihat bahwa dari 30 responden beragama islam (100\%) dengan perilaku hidup bersih dan sehat (PHBS) yang baik sejumlah 27 orang hal ini sesuai dengan ajaran agama islam yg tercantum dalam qur'an surat Al Baqarah ayat: 222 yang artinya dalam surat al-baqarah ayat 222 “ sungguh allah menyukai orang yang tobat dan menyukai orang yang menyucikan diri."

d. Karakteristik orang tua responden berdasarkan pendidikan

Berdasarkan tabel 4.4 diatas dapat dilihat bahwa dari 30 orang tua responden $0(0 \%)$ sekolah dasar,11 $(37 \%)$ orang tua responden berpendidikan SMP, 13 (43\%) orang tua responden berpendidikan SMA, $6(20 \%)$ orang tua responden berpendidikan perguruan tinggi di Desa Purwodadi Kecamatan Gisting Kabupaten Tanggamus tahun 2021. Tingkat pendidikan orang tua ini akan mempengaruhi pemahaman orang tua terhadap pentingnya perilaku hidup bersih dan sehat di tengah pandemi Covid-19. Pendidikan responden yang berpendidikan tinggi akan menyerap informasi, sehingga ilmu pengetahuan yang dimiliki tinggi namun sebaliknya orang tua yang berpendidikan rendah akan mengalami hambatan dalam penyerapan informasi sehingga ilmu yang dimiliki juga lebih rendah yang berdampak pada kehidupan (Irawati, 
2013). Menurut Astuti,et al., (2011) mengatakan pula tingkat pendidikan yang lebih tinggi akan mempermudah seseorang atau masyarakat memperoleh dan mencerna informasi dalam menerapkan hidup sehat.

e. Karakteristik orang tua responden berdasarkan usia

Berdasarkan tabel 4.6 diatas dapat dilihat bahwa dari 30 orang tua responden $6(20 \%)$ usia 28 tahun, orang tua responden yang usia 31 tahun $3(10 \%)$, orang tua responden yang berusia 40 tahun 4 (13\%), orang tua responden yang berusai 41 tahun $3(10 \%)$, orang tua responden yang berusia 42 tahun 5 (17\%), orang tua responden yang berusia 43 tahun $2(7 \%)$, orang tua responden yang berusia 44 tahun 1 (3\%), orang tua responden yang berusia 45 tahun $2(7 \%)$, orang tua responden yang berusia 59 tahun $3(10 \%)$ dan orang tua responden yang berusia 60 tahun $1(3 \%)$ di Desa purwodadi Kecamatan Gisting Kabupaten Tanggamus tahun 2021.

Usia akan mempengaruhi pemahman orang tua terhadap pentingnya perilaku hidup bersih dan sehat di tengah pandemi Covid19. Usia mempengaruhi daya tangkap dan pola fikir seseoarang.
Semakin bertambah usia akan semakin berkembang pola daya tangkap dan pola pikirnya sehingga pengetahuan yang di perolehnya semakin membaik. Pada usia madya, individu akan lebih berperan aktif dalam masyarakat dan kehidupan sosial, serta lebih banyak melakukan persiapan demi suksesnya upaya menyesuaikan diri menuju usia tua.

Menurut WHO, seseorang dikatakan memasuki usia lanjut (elderly), yaitu pada usia anatara 60-74 tahun. Di usia ini, seseoarang akan mengalami penurunan baik pada faktor fisik maupun psikisnya.(Sativa, 2020)

2. Hasil perilaku hidup bersih dan sehat (PHBS) responden

Dari hasil penelitian yang dilakukan pada 30 responden menunjukkan perilaku hidup bersih dan sehat (PHBS) pada anak usia dini di Desa Purwodadi Kecamatan Gisting Kabupaten Tanggamus tahun 2021 menunjukkan jumlah perilaku hidup bersih dan sehat anak usia dini baik sebanyak 27 (90\%) dikarnakan PHBS yang dilakukan oleh anak usia dini sudah dilakukan dengan baik salah satunya memcuci tangan sebelum makan dimana hal tersebut sudah banyak diterapkan setiap harinya dikarenakan adanya wabah Covid-19 
yang mewajibkan untuk semua orang hidup bersih dan sehat sehingga bisa mencegah Covid-19 yang terjadi saat ini. Sementara ada yang melakukan PHBS yaitu sebanyak 3 (10\%) cukup di Desa Purwodadi Kecamatan Gisting Kabupaten Tanggamus tahun 2021. Hasil penelitian ini sesuai dengan penelitian yang di lakukan oleh Anhusada (2020), tentang penerapan perilaku hidup bersih dan sehat anak usia dini di tengah pandemi Covid-19 di Kendari. Peneliti menggunakan teknik pengumpulan data berupa wawancara dan angket. Temuan dalam penelitian ini adalah sebanyak 100\% responden orang tua melihat sangat penting penerapan perilaku hidup bersih dan sehat selama pandemi Covid-19 ini. Sebanyak $98 \%$ atau 50 responden sudah mengetahu program perilaku hidup bersih. Penerapan perilaku hidup bersih dan sehat pada anak usia dini di lingkungan keluarga di tengah pandemi ini sangat baik.

\section{KESIMPULAN}

Dari hasil penelitian mengenai gambaran perilaku hidup bersih dan sehat di Desa Purwodadi Kecamatan Gisting Kabupaten Tanggamus tahun 2021 karakteristik responden berdasarkan usia 4-6 tahun, karakteristik berdasarkan jenis kelamin laki-laki dan perempuan, karakteristik agama responden $100 \%$ islam, karakteristik pendidikan orang tua responden SMP 11(37\%), SMA 13(43\%), Perguruan tinggi 6(20\%). Sebagia besar perilaku hidup bersih dan sehat (PHBS) responden masuk dalam katogori baik dengan jumlah 30 responden terdapat 3 (10\%) dengan perilaku hidup bersih dan sehat cukup, 27 (90\%) perilaku hidup bersih dan sehat baik di Desa purwodadi Kecamatan Gisting Kabupaten Tanggamus tahun 2021

\section{KEPUSTAKAAN}

Anhusadar. (2021). Penerapan perilaku hidup bersih dan sehat anak usia dini di tengah pandemi covid-19. Diunduh dari_https://obsesi.or.id. Pada tanggal 25 januari 2021

Bramasta.(2021). Update Covid-19 Januari: 95 juta kasus| WHO: Dunia di Ambang "BencanaMoral", Diunduhdar ihttps://www.kompas.com/tren/read/2021/ 01/19/075500365/update-covid-19januari-95-juta-kasus-who-dunia-diambang Pada tanggal 27 januari 2021

Hadiyatna. (2021). Data covid-19 januari di lampung. Diunduh dari https://m.antaranew.com/amp/berita/1965 404/dinkes-catat-positif-covid-19lampung-capai-9084-kasus .Pada tanggal 27 januari 2021

Hidayat. (2021). Data covid-19 di tanggamus dan gisting.Diunduh dari sicorona.tanggamus.go.id. $\quad$ Pada tanggal 27 januari 2021

Hadiyatna. (2021). Data covid-19 januari di lampung. Diunduh dari https://m.antaranew.com/amp/berita/1965 404/dinkes-catat-positif-covid-19lampung-capai-9084-kasus .Pada tanggal 27 januari 2021 
Kemenkes. (2020). Gambaran umum

Coronavirus dan tanda gejala covid19

Moerti. (2021).Data terkini Covid-19 di Indonesia Januari 2021.Diunduh dari http://m.merdeka.com/peristiwa/dataterkini-covid-19-di-indonesiajanuari2021.html Pada tanggal 27 januari 2021

Ramlan.D: (2021). Dampak Covid 19 Terhadap pertumbuhan Ekonomi Dan Pendidikan Secara Psikologis Di Negar-Negara ASEAN. Diunduh dari https://uma.ac.id/berita/dampak-covid-19terhadap-pertumbuhan-ekonomi-danpendidikan-secara-psikologisdinegaranegara-acean. Pada tanggal 27 febuari 